Bogusław Pietrzak

Katarzyna Wasiak ${ }^{1}$

\title{
STABILNOŚĆ I BEZPIECZEŃSTWO SYSTEMU BANKOWEGO - ASPEKTY INSTYTUCJONALNE I OPERACYJNE
}

\section{Wprowadzenie}

System bankowy, jako wiodące ogniwo systemu finansowego, podlega ciągłemu oddziaływaniu wielu czynników, mogących negatywnie wpływać na jego stabilność i bezpieczeństwo. To zaś, ze względu na istotną jego rolę w gospodarce i społeczeństwie, ma poważne znaczenie dla bezpieczeństwa całego systemu ekonomiczno-społecznego państwa. Dlatego też dla stworzenia efektywnego i skutecznego systemu zabezpieczającego sprawne funkcjonowanie sektora bankowego konieczne jest precyzyjne określenie zestawu podstawowych wymogów (warunków) instytucjonalnych i operacyjnych decydujących o jego stabilności i bezpieczeństwie. $Z$ tego też względu celem artykułu czynimy przeprowadzenie analizy wybranych czynników oddziałujących na funkcje, zasady, sposoby i metody działania dwu członów współczesnych systemów bankowych, tj. banku centralnego i banków komercyjnych, warunkujących ich stabilne i bezpieczne funkcjonowanie oraz wzmacniające wiarygodność instytucji i rynków finansowych. Bez tego dochodzić może (i dochodzi) do naruszenia (z wszelkiego typu konsekwencjami nie tylko natury ekonomicznej, ale również społecznej i politycznej) podstawowych zasad i warunków bezpieczeństwa narodowego. Struktura artykułu odpowiada temu zamierzeniu. W pierwszej części prezentujemy swoje stanowisko w sprawie określenia pojęcia stabilności i bezpieczeństwa systemu bankowego. W drugiej dokonujemy analizy roli poszczególnych instytucji wchodzących w skład sieci bezpieczeństwa finansowego w zapewnieniu warunków stabilizacji badanego systemu. W trzeciej określamy konieczne wymogi tej stabilizacji,

\footnotetext{
1 Prof. dr hab. Bogusław Pietrzak, dr Katarzyna Wasiak, Katedra Skarbowości, Kolegium Ekonomiczno-Społeczne, Szkoła Główna Handlowa w Warszawie.
} 
kierowane pod adresem systemu zarządzania instytucjami bankowymi. W zakończeniu formułujemy wnioski z przeprowadzonej analizy.

\section{Określenie pojęcia stabilności i bezpieczeństwa systemu bankowego}

Pojęcie stabilności i bezpieczeństwa sektora bankowego jako głównego ogniwa systemu finansowego można określić na podstawie szeroko prezentowanych obecnie $\mathrm{w}$ literaturze (m.in. pod wpływem ostatniego globalnego kryzysu) definicji stabilności tego systemu. Niestety, nie jest to zadanie proste ze względu na brak jednolitego stanowiska dotyczącego tego pojęcia. Obraz tej niejednoznaczności prezentuje wielu autorów, dokonując przeglądu tych definicji². Sam termin stabilności finansowej zaczął coraz częściej pojawiać się literaturze w latach 80. i 90. XX w. Przedtem raczej używano pojęcia stabilności poziomu cen czy stabilności walutowej.

Analizując stabilność finansową, z jednej strony można wskazać na cechy (czynniki), które system ten powinien posiadać, aby można było mówić o jego stabilności. O czynnikach tych piszą m.in. A. Crockett ${ }^{3}$, J. Lager ${ }^{4}$, M. Foot ${ }^{5}$, T. Padoa-Schioppa ${ }^{6}$, G. Schinasi ${ }^{7}$. Inni autorzy, jak np. F.S. Mishkin ${ }^{8}$, E. Davies ${ }^{9}$, R. Ferguson ${ }^{10}$, J. Chant ${ }^{11}$,

2 M. Iwanicz-Drozdowska, Definicje i determinanty stabilności finansowej, w: Stabilność finansowa, red. M. Iwanicz-Drozdowska, NBP, Warszawa 2014; P. Smaga, Rola banku centralnego w zabezpieczaniu stabilności finansowej, CeDeWu, Warszawa 2014; A. Matysek-Jędrych, Odpowiedzialność i przejrzystość banku centralnego na rzecz stabilności finansowej, „Materiały i Studia NBP” 2014, nr 303.

3 A. Crockett, Why is Financial Stability a Goal of Public Policy?, w: Maintaining Financial Stability in a Global Economy, Symposium Proceedings, Federal Reserve Bank of Kansas City, August 1997, s. 55-96.

4 J. Lager, Monitoring Financial System Stability, „Reserve Bank of Australia Bulletin” October 1999.

5 M. Foot, What is "financial stability" and How do we get it?, The Roy Bridge Memorial Lecture, Financial Services Authority, April 2003.

6 T. Padoa-Schioppa, Central Banks and Financial Stability: Exploring a Land in Between, paper presented at the Second ECB Central Banking Conference, Frankfurt am Main, 24-25 October 2002.

7 G. Schinasi, Defining Financial Stability, „IMF Working Paper” October 2004, No. WP/04/187.

8 F. Mishkin, The Causes and Propagation of Financial Instability: Lessons for Policymakers, w: Maintaining Financial Stability in a Global Economy, Symposium Proceedings, Federal Reserve Bank of Kansas City, August 1997, s. 55-96; F. Mishkin, Global Financial Instability: Framework, Events, Issues, „Journal of Economic Perspectives" Autumn 1999, Vol. 13, No. 4, s. 3-20; F. Mishkin, Financial Stability and the Macroeconomy, „Central Bank of Iceland Working Paper” May 2000, No. 9.

9 E. Davis, A Typology of Financial Instability, „OesterreichischeNationalbank (Central Bank of Austria) Financial Stability Report" 2001, No. 2, s. 92-110

10 R. Ferguson, Should Financial Stability Be an Explicit Central Bank Objective?, w: Monetary Stability, Financial Stability and the Business Cycle: Five Views, „BIS Paper” September 2003, No. 18, s. 7-15.

11 J. Chant, Financial Stability as a Policy Goal, w: Essays on Financial Stability, „Technical Report Bank of Canada" September 2003, No. 95. 
W. Allen i G. Wood ${ }^{12}$, koncentrują się raczej na uszczegółowieniu terminu niestabilności finansowej oraz przyczyn jej powstawania. Syntetyczne podsumowanie oraz porównanie tych definicji można znaleźć np. w pracy A.A. Alawode i M.A. Sadek. Warto zwrócić uwagę, że w definicjach stabilności finansowej często znajdujemy odniesienie do funkcji systemu finansowego ${ }^{13}$.

Potwierdza to również M. Iwanicz-Drozdowska, wskazując zarówno na stanowiska wyrażane w tej sprawie przez czołowych przedstawicieli światowej nauki, jak i przez wybrane banki centralne. Autorka dochodzi do słusznego wniosku, że definicje stabilności systemu finansowego „mają wspólną cechę - wskazują, że w przypadku szoków system finansowy będzie w stanie wypełniać przypisane mu funkcje” ${ }^{14}$. $\mathrm{Na}$ tę cechę wyrażoną $\mathrm{w}$ definicjach zwrócimy szczególną uwagę w tym artykule, m.in. ze względu na to, że polski bank centralny - Narodowy Bank Polski przyjmuje w swoich dokumentach definicję następującą: „Stabilność systemu finansowego to stan, w którym pełni on swoje funkcje w sposób ciągły i efektywny, nawet w przypadku wystąpienia nieoczekiwanych i niekorzystnych zaburzeń o znacznej skali”'15.

$\mathrm{W}$ przeprowadzonej analizie, przyjmując tę definicję i odnosząc ją do systemu bankowego, koncentrować się będziemy na funkcjach dwu ogniw tego systemu, tj. banku centralnego i banków komercyjnych. W przypadku banku centralnego za istotne uznajemy kwestie związane $\mathrm{z}$ wypełnianiem funkcji banku państwa, banku banków i banku emisyjnego. W odniesieniu do banków komercyjnych interesujące i niezwykle ważne jest to, że ich funkcjonowanie opiera się na dwu kryteriach: kryterium rynkowym i kryterium zaufania publicznego, co oznacza, że jako podmioty gospodarki rynkowej działają według zasad tej gospodarki, ale jednocześnie - ponieważ ich funkcjonowanie opiera się głównie na zasobach dostarczanych przez akcjonariuszy i deponentów, które są podstawą świadczenia usług przynoszących dochód - muszą nieustannie dbać o swoją wiarygodność i zaufanie klientów, a także aktywnie uczestniczyć w realizacji społecznej odpowiedzialności biznesu oraz w kształtowaniu reputacji.

Odnosząc się do relacji stabilności i bezpieczeństwa systemu bankowego, przyjmujemy, że bezpieczny system to taki, który cechuje się wysokim poziomem stabilności oraz charakteryzuje się gwarancją utrzymującego się ciągle zaufania (wiarygodności) swoich klientów. Takie stanowisko prezentuje J. Koleśnik, który uznaje, iż bezpieczny

12 W. Allen, G. Wood, Defining and achieving financial stability, „Journal of Financial Stability” June 2006, s. $152-172$

13 K. Wasiak, Stabilność systemu finansowego a cykl koniunkturalny, w: Polityka monetarna i fiskalna a stabilność sektora finansowego, red. A. Alińska, CeDeWu, Warszawa 2012, s. 148-149.

14 M. Iwanicz-Drozdowska, op.cit., s. 6.

15 Raport o stabilności systemu finansowego, NBP, Warszawa 2014, s. 3. 
system bankowy to „system, który cieszy się zaufaniem większości akcjonariuszy, w tym szczególnie: deponentów, kontrahentów, właścicieli instytucji sieci bezpieczeństwa, pomimo ryzyka, które związane jest z jego działalnością"16.

Można więc przyjąć, że stabilność systemu bankowego jest warunkiem jego bezpieczeństwa. W związku z tym dokonując analizy czynników skutecznie działających na rzecz stabilności, uzyskujemy również obraz kształtowania się pod ich wpływem bezpieczeństwa tego wiodącego ogniwa systemu finansowego.

\section{Sieć bezpieczeństwa finansowego jako instytucjonalne zaplecze stabilności i bezpieczeństwa systemu bankowego}

W systemie bankowym szczególnie silnie działa tzw. efekt domina (zarażania). Polega on na tym, że trudności w funkcjonowaniu czy też upadek jednego banku na skutek istnienia różnorodnych powiązań prowadzi do kłopotów, a nawet upadku innych banków. Z kolei kryzys w sektorze bankowym przenosi się na pozostałe ogniwa całego systemu finansowego, rozpowszechnia się na inne kraje oraz regiony, przyjmując globalny charakter, i dociera do sfery realnej stanowiącej podstawę materialną funkcjonowania gospodarki i społeczeństwa. Dlatego też w celu wzmocnienia bezpieczeństwa banków wykorzystuje się szeroki zestaw środków, wśród których znajdują się odpowiednie uregulowania w ustawodawstwie finansowym (monetarnym i fiskalnym), nadzór bankowy z jego uprawnieniami i regulacjami ostrożnościowymi, systemy i instytucje ubezpieczające depozyty oraz gwarantujące kredyty, a także controlling z jego podstawowymi obszarami działania.

Stabilność i bezpieczeństwo systemu bankowego wzmacniają również inne instytucje: nadzór właścicielski sprawowany przez akcjonariuszy i audytorów zewnętrznych oraz organizacje zrzeszające banki. O bezpieczeństwie banków decyduje także zestaw czynników makroekonomicznych związanych z kondycją gospodarki, charakterem prowadzonej polityki gospodarczej, w tym zwłaszcza finansowej (monetarnej i fiskalnej).

Szczególne znaczenie posiada w tym zakresie sieć bezpieczeństwa finansowego. Można ją określić jako zespół instytucji, ze ściśle określonymi uprawnieniami i kompetencjami. Instytucje te powołane są, aby chronić system finansowy (w tym bankowy jako wiodące ogniwa tego systemu) i jego klientów przed negatywnymi konsekwencjami destabilizacji, wywołanej skutkami ryzyka występującego na rynkach

16 J. Koleśnik, Bezpieczeństwo systemu bankowego. Teoria i praktyka, Difin, Warszawa 2011, s. 54. 
finansowych i działających na nich instytucji, dysponujących instrumentami finansowymi w ramach świadczonych usług.

Sieć bezpieczeństwa finansowego, w której skład wchodzą rządy, banki centralne, instytucje nadzoru finansowego oraz gwarantowania depozytów, jest elementem współczesnej architektury (infrastruktury) finansowej. Jej rola wyraźnie wzrosła w okresie ostatniego kryzysu, choć sieć ta została powołana w poszczególnych krajach już przed kryzysem, w związku z narastającymi zagrożeniami związanymi z dynamicznie rosnącym znaczeniem ryzyka $w$ działalności instytucji finansowych. Wchodzące w skład sieci bezpieczeństwa finansowego instytucje muszą mieć tak określone kompetencje i zadania, aby w wyniku ścisłego współdziałania osiągnąć pożądany stan stabilności systemu finansowego, w tym systemu bankowego.

W literaturze i praktyce panuje zgodność co do tego, że stabilność systemu finansowego (w tym oczywiście bankowego) i jego bezpieczeństwo należy traktować jako swoistego rodzaju dobro publiczne, które powinno być dostarczane społeczeństwu w dostatecznej wielkości, o które trzeba dbać, wykazywać o nie najwyższej rangi troskę, ponieważ nie jest ono dane raz na zawsze.

Jak wspomnieliśmy, sieć bezpieczeństwa finansowego funkcjonowała już w okresie przed 2007 r. Niestety, do czasu kryzysu w wielu krajach, mimo formalnego istnienia sieci bezpieczeństwa finansowego, jej działanie charakteryzowało się często brakiem ściśle określonych kompetencji i zasad funkcjonowania poszczególnych ogniw oraz trudnościami w ich koordynacji. Monitorowanie sytuacji systemu finansowego i wykonywanie zadań wynikających z przypisanych poszczególnym instytucjom wchodzącym w jej skład, funkcji dotyczących przeciwdziałania narastającym tendencjom kryzysowym oraz materializacji ryzyka systemowego okazało się niewystarczające.

Określając w sposób najbardziej syntetyczny rolę wymienionych ogniw sieci, należy stwierdzić, iż w ramach realizowanych funkcji finansów publicznych: redystrybucyjnej, alokacyjnej i stabilizacyjnej - na rządach musi spoczywać przede wszystkim obowiązek prowadzenia polityki fiskalnej zapewniającej dyscyplinę budżetową przejawiającą się $\mathrm{w}$ trosce o jej równowagę, wyrażającą się w kształtowaniu ściśle określonych wymogów dotyczących deficytu budżetowego i długu publicznego. Istotną rolą rządu jest przygotowanie skutecznych regulacji i norm prawnych gwarantujących stabilne i bezpieczne funkcjonowanie instytucji finansowych. Rząd jako dysponent środków publicznych wykazywać się musi ciągłą, systematyczną i konsekwentną troską o racjonalizację wydatków publicznych.

Mimo że od wieków toczy się dyskusja nad zakresem działalności państwa (rządów) w sferze gospodarczej i społecznej, możliwości i celowości angażowania się w racjonalne wydatkowanie środków publicznych, doborem i sposobami wykorzystania 
odpowiednich metod zabezpieczających efektywne ich wykorzystywanie, to w dalszym ciągu aktualnym i niezwykle ważnym problemem są poszukiwania coraz bardziej skutecznych metod racjonalizacji wydatków publicznych. Równowaga w sferze finansów publicznych sprzyja bowiem stabilności i bezpieczeństwu systemu finansowego m.in. dlatego, że w takich warunkach utrwala się pozycja i wartość pieniądza.

Chcielibyśmy w tym miejscu (w którym analizujemy rolę rządu odpowiedzialnego za realizację polityki fiskalnej i jego miejsce w sieci) zwrócić uwagę na jeszcze jeden problem konieczny do uwzględnienia $w$ ramach działań na rzecz stabilności i bezpieczeństwa systemu finansowego, w tym bankowego. Mamy tu na myśli kwestie związane z potrzebą koordynacji polityki fiskalnej i monetarnej jako dwu członów polityki finansowej państwa ${ }^{17}$.

Do czasu kryzysu stanowiska wielu autorów dotyczące warunków i efektów koordynacji polityki fiskalnej i monetarnej były wielce zróżnicowane, choć generalnie dostrzegano wagę tego zagadnienia. Tym niemniej osiągnięcie stanu satysfakcjonującej koordynacji było zjawiskiem nader rzadkim. Okres ostatnich kilku lat przyniósł nowe doświadczenia wskazujące m.in. na konieczność intensyfikacji działań interwencyjnych ze strony władz monetarnych i fiskalnych. Można więc stwierdzić, że potwierdzeniem konieczności podjęcia działań na rzecz koordynacji polityki monetarnej i fiskalnej jest skala wpływu światowego kryzysu finansowego na sytuację sektora finansów publicznych oraz stabilność systemu finansowego, w tym zwłaszcza sektora bankowego realizującego w sensie operacyjnym programy polityki monetarnej opracowane przez bank centralny Wyraźnie zaznaczył się wzrost deficytu budżetowego oraz długu publicznego. Pojawiają się problemy strukturalne, które były wcześniej mniej widoczne w związku z szybko rozwijającą się gospodarką i wysokimi dochodami budżetowymi. Spadki dochodów przy względnie sztywnej strukturze wydatków publicznych spowodowały silny wzrost deficytu sektora finansów publicznych. W tej sytuacji dla zrealizowania zadania obniżenia skali nierównowagi finansów publicznych, zahamowania niekorzystnych tendencji w sferze deficytu budżetowego oraz narastania długu publicznego, a w rezultacie konieczności zrealizowania zobowiązań nakładanych np. w ramach procedury nadmiernego deficytu oraz wynikających z ustalonych dla kraju ubiegającego się o wejście do strefy euro budżetowych i monetarnych kryteriów konwergencji nakazem jest stosowanie wariantu ściślejszego współdziałania władz fiskalnych i monetarnych.

17 B. Pietrzak, K. Wasiak, O potrzebie koordynacji polityki fiskalnej i monetarnej, w: O nowy model dziatalności regulacyjnej państwa w sferze finansów. Książka jubileuszowa prof. dr. hab. S. Owsiaka, red. A. Moździerz, PWE, Warszawa 2011. 
Dodatkowym argumentem są tu aktualne doświadczenia i przewidywany rozwój sytuacji w sferze finansów publicznych wielu państw borykających się z nadmierną nierównowagą sektora finansów publicznych. Wyraźnie widać, iż w wyniku ostatniego kryzysu, którego istotnym źródłem były nieprawidłowości w funkcjonowaniu systemu finansowego, w tym w szczególności bankowego, a „kozłem ofiarnym" ogromny wzrost wydatków budżetowych, pojawiło się potężne potencjalne (które może się przerodzić $\mathrm{w}$ realne) niebezpieczeństwo, iż to narastanie deficytów budżetowych i długu publicznego w wielu krajach stanie się nowym źródłem kryzysu o charakterze międzynarodowym. Skutkami owych tendencji może zostać również dotknięta sfera monetarna, głównie ze względu na niebezpieczeństwo silnej presji inflacyjnej wywieranej przez ogromny wzrost strumieni pieniężnych w gospodarkach wielu krajów. Aby uniknąć w przyszłości przykrych konsekwencji, należy pilnie wyciągnąć wnioski z dotychczasowych działań koordynacyjnych (będących m.in. wynikiem funkcjonowania w okresie kryzysu sieci bezpieczeństwa finansowego, których głównymi ogniwami są rządy i banki centralne) polityki fiskalnej i monetarnej.

Potwierdzenie wagi koordynacji widoczne jest zwłaszcza w warunkach nadzwyczajnych, kryzysowych, co skutkuje wzmożoną dyskusją na ten temat w ostatnich latach. Brak wiarygodności policy mix, zwłaszcza w długim okresie, zmniejsza efektywność instrumentów polityki pieniężnej. Z kolei brak wiarygodności polityki pieniężnej w znacznie większym stopniu obciąża politykę fiskalną, gdyż prowadzi do wzrostu stóp procentowych. W długim okresie należy zadbać o to, aby koordynacja polityki fiskalnej i monetarnej sprzyjała utrzymywaniu się gospodarki na zrównoważonej ścieżce wzrostu, ze stabilnym poziomem cen oraz sektorem finansów publicznych sprzyjający temu wzrostowi. Oznacza to, że deficyt budżetowy musi być utrzymywany na poziomie, który pozwala na osiągnięcie i utrzymanie takich warunków, a zatem powinien być finansowany przez operacje na rynku kapitałowym, bez tworzenia zniekształceń w alokacji pieniądza w gospodarce, bez potrzeby finansowania przez bank centralny oraz bez nadmiernego zadłużenia zewnętrznego. Konieczne jest przy tym właściwe zarządzanie długiem publicznym ${ }^{18}$. Należy jednak zdawać sobie sprawę z tego, że zarówno teoria, jak i praktyka nie dają jednoznacznych odpowiedzi na pytanie o najwłaściwszy model koordynacji polityki fiskalnej i monetarnej. Tym bardziej temat pozostaje ważny i aktualny.

Jeśli chodzi o pozycję banków centralnych w sieci bezpieczeństwa finansowego, to należy w pierwszej kolejności zauważyć, że podstawową sprawą są tu przypisane

18 B. Laurens, E.G. de la Piedra, Coordination of Monetary and Fiscal Policies, „IMF Working Paper” March 1998, No. 98/25, s. 4-6. 
tym instytucjom funkcje: banku państwa, banku emisyjnego i banku banków ${ }^{19}$. Do każdej z tych funkcji należy podchodzić w taki sposób, który wskazuje szeroką ich interpretację i praktyczne wykorzystanie w sieci bezpieczeństwa. Wąskie, podręcznikowe, tradycyjne podejście do funkcji banku centralnego w warunkach współczesnych jest już niewystarczające.

Po pierwsze, niewątpliwie bank centralny występując w roli banku państwa i realizując tak pożyteczne zadanie jak obsługa rachunków władz centralnych i terenowych (samorządowych), przeprowadzanie w ich imieniu operacji finansowych krajowych i zagranicznych, dysponowanie rezerwami złota i dewiz, nadzorowanie transakcji kredytowych z zagranicą, zaciąganie i spłata kredytów zagranicznych, wpływa stabilizująco na system finansowy. Ale główna jego rola w tej funkcji musi polegać na spełnieniu zadań wynikających z tego, iż jest najważniejszym organem państwa w tej dziedzinie polityki gospodarczej, która dotyczy sfery monetarnej. Jako władza monetarna jest odpowiedzialny za stabilizację wartości pieniądza. Tak jak inne ogniwa systemu gospodarczego odpowiedzialne są za stabilizację poszczególnych segmentów polityki gospodarczej, podobnie bank centralny jest jedyną instytucją, której konstytucyjnie powierza się dbałość o hamowanie tendencji inflacyjnych.

Po drugie, wprawdzie współczesny bank centralny pełniąc funkcję banku emisyjnego, kojarzony jest z instytucją posiadającą przywilej (monopol) emitowania pieniądza gotówkowego, trzeba jednak pamiętać, iż w ramach tej funkcji należy umieścić również oddziaływania na ogólną podaż oraz organizowanie obiegu pieniężnego. Zadania te mogą być prawidłowo realizowane jedynie w warunkach stabilności systemu bankowego, co określa konieczność zainteresowania banku centralnego ową stabilnością.

Po trzecie, pełnienie funkcji banku banków oznacza nie tylko to, że na rachunkach w tym banku utrzymują rezerwy pieniężne banki komercyjne, ale również to, że jest on dla nich źródłem rezerwy kredytowej (pożyczkodawcą ostatniej instytucji), a więc ma możliwości skutecznego oddziaływania na płynność w systemie bankowym, wielkość akcji kredytowej banków oraz na rozmiary kreowania pieniądza bezgotówkowego stanowiącego decydującą część ogólnej podaży pieniądza, co w rezultacie wpływa na jego stabilizację. Rolę tej funkcji podkreśla C. Wójcik, pisząc: „Stabilność systemu bankowego gwarantowana jest poprzez obecność banku centralnego, który odgrywa wobec banków rolę pożyczkodawcy ostatniej instytucji. Piękno tego rozwiązania polega na tym, że sama zapowiedź dostarczenia środków przez bank centralny zmniejsza ryzyko załamania systemu [... $]^{\prime 20}$.

19 B. Pietrzak, System bankowy, w: System finansowy w Polsce, t. 1, red. B. Pietrzak, Z. Polański, B. Woźniak, Wydawnictwo Naukowe PWN, Warszawa 2008.

20 C. Wójcik, Co z druga fala kryzysu, „Rzeczpospolita” 25 sierpnia 2011. 
W tym miejscu warto podkreślić, że funkcja pożyczkodawcy ostatniej instancji zyskała w ostatnich latach, zwłaszcza po kryzysie z 2007 r., na znaczeniu, choć jest jedną z najstarszych funkcji banku centralnego. Została sformułowana po raz pierwszy w XIX w. przez H. Thorntona ${ }^{21}$ i W. Bagehota ${ }^{22}$, którzy określi ją jako dyskrecjonalne zasilenie w płynność pojedynczego banku lub całego systemu bankowego w reakcji na niekorzystny szok wywołujący nadzwyczajny wzrost popytu na pieniądz rezerwowy, który nie może zostać zaspokojony z innych źródeł (np. prywatnych). Współczesne banki centralne, szczególnie w gospodarkach rozwiniętych, stają się coraz częściej nie tylko kreatorami polityki pieniężnej i pożyczkodawcami ostatniej instancji dla banków, ale także dla całych gospodarek. W tym miejscu warto zacytować opinię M. Zaleskiej, która pisze, że banki centralne postrzegane są jako najlepsze antidotum, ratunek i środek na rozwiązanie wszystkich problemów (w tym gospodarczych, socjalnych i politycznych). Nie umniejszając roli banków centralnych, traktowanie ich instrumentalnie, jako podmioty mające "nieograniczone” zasoby finansowe i mogące rozwiązać wszelkie wyzwania, jest niewłaściwe i niebezpieczne. A zatem być może - w odpowiedzi na współczesny kryzys - kolejna teoria ekonomiczna, określająca rolę banków centralnych jako niezależnych kreatorów polityki pieniężnej i pożyczkodawców ostatniej instancji dla banków, „legła w gruzach”. Tym samym może banki centralne tracą w jakimś stopniu niezależność, a jednocześnie rozbudowując zasięg swojego oddziaływania, działają w nowych obszarach (np. nadzoru makroostrożnościowego), stając się „superrządami”23.

Wymienione funkcje banku centralnego łączą się ściśle z jego dotychczasowym podstawowym celem związanym ze stabilnością monetarną, ona zaś z przedsięwzięciami nakierowanymi na stabilność sektora bakowego. Wynika to z tego, iż dbałość o skuteczne wypełnianie funkcji banku państwa, banku emisyjnego i banku banków, których istotą jest to, iż bank centralny jest najważniejszym organem państwa w dziedzinie polityki gospodarczej dotyczącej sfery monetarnej i jest odpowiedzialny za stabilizację pieniądza, powiązana jest $\mathrm{z}$ koniecznością troski o instytucjonalne zaplecze realizacji polityki pieniężnej, zwłaszcza za stan systemu bankowego. Pożądane efekty w sferze realizacji zadań dotyczących kontroli podaży pieniądza można uzyskiwać jedynie w warunkach stabilności systemu bankowego. Bank centralny wykorzystując pozostające w jego dyspozycji instrumenty polityki pieniężnej, powinien

$21 \mathrm{H}$. Thornton, The evidence given by Henry Thornton before the Committees of Secrecy of the Two Houses of Parliament on the Bank of England, March and April 1797; T.M. Humphrey, Lender of last resort: What it is, whence it came, and why the Fed isn't it, "Cato Journal” 2010, Vol. 30, No. 2.

22 W. Bagehot, Lombard Street: A Description of the Money Market, H.S. King, London 1873.

23 M. Zaleska, Społeczeństwa szybko zapominają o przyczynach kryzysów, „Obserwator Finansowy NBP” wrzesień 2015, www.obserwatorfinansowy.pl 
skutecznie oddziaływać na płynność systemu bankowego, co w rezultacie wpływa zarówno na jego stabilizację, jak i bezpieczeństwo.

W sposób precyzyjny i przekonywający zależności te ujęła O. Szczepańska, pisząc: „Stabilność cen i stabilność finansowa są ze sobą ściśle powiązane, a zależność między tymi dwoma celami jest obustronna. Kondycja finansowa determinuje warunki realizacji polityki pieniężnej, natomiast skuteczność polityki pieniężnej ma wpływ na kształtowanie się sytuacji w tym systemie. Owa wzajemna relacja sprawia, iż banki centralne, będące formalnie odpowiedzialne za stabilność cen, są zainteresowane również tym, aby system finansowy działał sprawnie i spełniał prawidłowo swoje funkcje"24.

O dużym znaczeniu owych relacji świadczy m.in. to, że:

- instrumenty polityki pieniężnej (stopa procentowa, operacje otwartego rynku, stopa rezerw obowiązkowych, operacje kredytowo-depozytowe), oddziaływając regulująco na płynność w sektorze bankowym, możliwą do zrealizowania wielkość akcji kredytowej i podaż pieniądza, wpływają jednocześnie na stabilizację warunków działania banków komercyjnych;

- stabilność systemu bankowego czy szerzej systemu finansowego jest warunkiem pomyślnej realizacji założeń polityki pieniężnej poprzez skuteczne działanie mechanizmu transmisji impulsów polityki pieniężnej i w rezultacie osiągnięcie pożądanego celu w postaci stabilności cen;

- banki centralne są instytucjami o długiej i bogatej historii aktywnego udziału w realizacji zadań na rzecz stabilności systemu finansowego;

- współcześnie koniecznością jest troska banków centralnych o realne, a nie tylko formalne spełnienie przypisanych im podstawowych, jakościowych kryteriów funkcjonowania, takich jak: niezależność, przejrzystość działania, wiarygodność i społeczna odpowiedzialność ${ }^{25}$.

Ciągła dbałość o spełnienie tych kryteriów pozytywnie oddziałuje na stabilizację i bezpieczeństwo systemu bankowego poprzez związki, jakie zachodzą między bankiem centralnym a bankami komercyjnymi realizującymi w sensie operacyjno-wykonawczym przyjęte w założeniach polityki pieniężnej zadania.

W ramach podjętej już w trakcie ostatniego kryzysu (i pod wpływem negatywnych jego skutków) dyskusji związanej z odpowiedzialnością banków centralnych za stabilność systemu finansowego, a w szczególności systemu bankowego uznano, iż współczesne banki centralne powinny traktować ową stabilność jako priorytetowy,

24 O. Szczepańska, Stabilność finansowa jako cel banku centralnego. Studium teoretyczno-porównawcze, Wydawnictwo Naukowe Scholar, Warszawa 2008, s. 40.

25 M. Kowalak, Jakościowe aspekty polityki współczesnego banku centralnego, „Bank i Kredyt” 2006, nr 3. 
obok stabilności monetarnej (stabilność cen, stabilność wartości pieniądza), cel w swojej działalności. Z tym stanowiskiem w pełni się utożsamiamy. Dotyczy to np. propozycji umiejscowienia w bankach centralnych nadzoru makroostrożnościowego, na co będziemy wskazywać w niżej przedstawionych rozważaniach dotyczących roli nadzoru w sieci bezpieczeństwa.

Kolejną instytucją wchodzącą w skład sieci bezpieczeństwa finansowego jest nadzór finansowy, w którym wiodącą, ze względu na wagę sektora bankowego w systemie finansowym, rolę odgrywał do czasu kryzysu nadzór mikroostrożnościowy nad poszczególnymi bankami, spełniając cztery podstawowe funkcje: licencyjną, regulacyjną, kontrolną oraz dyscyplinującą.

Doświadczenia kryzysu wykazały, że funkcjonowanie nadzoru jedynie w odniesieniu do pojedynczych instytucji oraz koncentracja nad ochroną przed konsekwencjami ryzyka operacyjnego banków (głównie płynności, kredytowego, walutowego i stopy procentowej) są niewystarczające, gdyż nie uwzględniają skutków ryzyka systemowego. W tej sytuacji powstała konieczność uzupełnienia sieci bezpieczeństwa finansowego o instytucję (czy też zbiór instytucji) odpowiedzialną za prowadzenie nadzoru makroostrożnosciowego o charakterze prewencyjnym, którego zadaniem byłoby głównie zapobieganie zagrożeniom w systemie bankowym, a nie tylko rozwiązywanie sytuacji kryzysowych w poszczególnych bankach.

Tak więc postulat (już wdrażany w wielu krajach) zwiększenia roli nadzoru w sieci bezpieczeństwa finansowego wyraźnie zmierza do wzmocnienia siły oddziaływania sieci na utrzymanie stabilności i bezpieczeństwa systemu bankowego ${ }^{26}$. We wrześniu 2015 r. została podpisana przez Prezydenta RP Ustawa z dnia 5 sierpnia 2015 r. o nadzorze makroostrożnościowym nad systemem finansowym i zarządzaniu kryzysowym w systemie finansowym ${ }^{27}$. Zgodnie $\mathrm{z}$ ustawą nadzór makroostrożnościowy nad systemem finansowym obejmuje identyfikację, ocenę i monitorowanie ryzyka systemowego powstającego w systemie finansowym lub jego otoczeniu oraz działanie na rzecz wyeliminowania lub ograniczania tego ryzyka z wykorzystaniem instrumentów makroostrożnościowych. Celem nadzoru jest wzmacnianie odporności systemu

26 A. Dobrzańska, Polityka makroostrożnościowa - zagadnienia instytucjonalne. Teoria i dotychczasowe doświadczenia w Unii Europejskiej, „Materiały i Studia NBP” 2014, nr 307.

27 Ustawa:

- w zakresie swojej regulacji wdraża Dyrektywę Parlamentu Europejskiego i Rady nr 2013/36/UE z dnia 26 czerwca 2013 r. w sprawie warunków dopuszczenia instytucji kredytowych do działalności oraz nadzoru ostrożnościowego nad instytucjami kredytowymi i firmami inwestycyjnymi, zmieniającą dyrektywę 2002/87/WE i uchylającą dyrektywy 2006/48/WE oraz 2006/49/WE, DzUrz. UE L 176 z 27.06.2013, s. 338, z późn. zm.,

- służy stosowaniu Rozporządzenia Parlamentu Europejskiego i Rady (UE) nr 575/2013 z dnia 26 czerwca 2013 r. w sprawie wymogów ostrożnościowych dla instytucji kredytowych i firm inwestycyjnych, zmieniającego rozporządzenie (UE) nr 648/2012, DzUrz. UE L 176 z 27.06.2013, s. 1, z późn. zm. 
finansowego na wypadek materializacji ryzyka systemowego i wspieranie przez to długookresowego, zrównoważonego wzrostu gospodarczego kraju. Zarządzanie kryzysowe w systemie finansowym obejmuje z kolei działanie na rzecz utrzymania lub przywrócenia stabilności systemu finansowego w przypadku bezpośredniego zagrożenia tej stabilności, a jego celem jest m.in. koordynacja działań podmiotów reprezentowanych przez członków Komitetu Stabilności Finansowej ${ }^{28}$ oraz wymiana informacji, opinii i ocen. Członkami Komitetu są: Minister Finansów, Prezes Narodowego Banku Polskiego, Przewodniczący Komisji Nadzoru Finansowego oraz Prezes Zarządu Bankowego Funduszu Gwarancyjnego. Należy mieć nadzieję na pozytywne rezultaty tego przedsięwzięcia ${ }^{29}$.

W tym miejscu trzeba wspomnieć o jeszcze jednej inicjatywie, z którą wiążą się również nadzieje na wzmocnienie i skonsolidowanie w skali europejskiej systemu nadzorczego nad stabilnością i bezpieczeństwem systemu bankowego. Mamy tu na myśli wdrażany projekt europejskiej unii bankowej, w której ramach wyodrębniono trzy wzajemnie uzupełniające się segmenty:

- jednolity mechanizm nadzoru (Single Supervisory Mechanism - SSM),

- europejski mechanizm restrukturyzacji i uporządkowanej likwidacji banków (Single Resolution Mechanism - SRM),

- europejski mechanizm gwarantowania depozytów (Single Deposit Guarantee Scheme - SDGS $)^{30}$.

Pełne wdrożenie wymienionych elementów europejskiej unii bankowej mogłoby stanowić, poprzez objęcie nimi podstawowych obszarów związanych z ryzykiem systemowym, poważne wzmocnienie krajowych sieci bezpieczeństwa finansowego. Unia bankowa jest jednak projektem niezakończonym. Dwa pierwsze segmenty rozpoczęły funkcjonowanie, natomiast trzeci nie jest w tej chwili wdrażany. Nie jest nam też znana decyzja, czy i kiedy prace nad SDGS ruszą dalej.

Systemy gwarantowania depozytów są kolejnym segmentem sieci bezpieczeństwa finansowego. Istotną sprawą jest to, aby zapewniały one nie tylko ochronę środków powierzonych w postaci depozytów bankom przez ich klientów, ale również miały możliwości i kompetencje w zakresie prowadzenia działalności pomocowej dla banków. Takie rozwiązanie funkcjonuje w Polsce. Pisze o nim M. Grzybowski, wskazując, że celem jest „w ramach rozwiązań [...] usuwanie niebezpieczeństwa niewypłacalności poprzez:

28 Uchylona została obecnie obowiązująca Ustawa z dnia 7 listopada 2008 r. o Komitecie Stabilności Finansowej.

29 Ustawa z dnia 5 sierpnia 2015 r. o nadzorze makroostrożnościowym nad systemem finansowym i zarządzaniu kryzysowym w systemie finansowym, DzU 2015, poz. 1513, art. 1,2,7.

30 Europejska Unia Bankowa, red. M. Zaleska, Difin, Warszawa 2015. 
- udzielenie pomocy finansowej bankom, które znalazły się w obliczu niewypłacalności i podejmują samodzielną sanację;

- wspieranie procesów łączenia się banków zagrożonych z bankiem o silnej pozycji, lub zmiany ich struktury własnościowej”31 ${ }^{31}$ musi być nastawione na realizację ważnej funkcji zaufania publicznego; wzmocnienie krajowych systemów gwarantowania depozytów wyżej wskazanym trzecim segmentem Europejskiej Unii Bankowej świadczy o determinacji w dążeniu do utworzenia kompleksowego i ponadnarodowego systemu bezpieczeństwa finansowego.

\section{Uwarunkowania stabilności i bezpieczeństwa w wewnętrznej sferze działania banków komercyjnych}

Jak już wcześniej stwierdziliśmy, funkcjonowanie banków komercyjnych opiera się na dwu kryteriach: kryterium rynkowym i kryterium zaufania publicznego. Z jednej strony banki komercyjne jako podmioty systemu finansowego działają zgodnie z logiką gospodarki rynkowej i dążą do realizacji funkcji celu związanej z efektami swojej działalności produkcyjnej i rynkowej (maksymalizacja zysku, stopy zysku, stopy rentowności, maksymalizacja udziału w rynku, czy też wartości rynkowej banku bądź wartości dla akcjonariuszy). Z drugiej, w odróżnieniu od innych jednostek gospodarczych określa się je często mianem instytucji zaufania publicznego, co oznacza, że w swojej działalności i w swoim dążeniu do maksymalizacji wymienionych wyżej wielkości muszą uwzględniać fakt gospodarowania powierzonymi im środkami w formie nie tylko kapitału obcego, lecz także depozytów, które z kolei są podstawą świadczenia usług (głównie kredytowych) przynoszących dochód. Inaczej mówiąc, banki muszą bezwzględnie dbać o zaufanie osób i instytucji dostarczających środki finansowe oraz osób i instytucji korzystających $z$ oferty produktowej. Zaufanie jako wymagana cecha banku komercyjnego stanowi zasadniczy czynnik stabilności i bezpieczeństwa systemu bankowego. Potwierdziły to m.in. doświadczenia ostatniego kryzysu, jak również przykłady wielu banków z okresów stabilizacji gospodarczej i finansowej. Trafnie określił to C. Wójcik, pisząc: „Podstawą stabilności systemu bankowego jest coś bardzo ulotnego - zaufanie. Gdy ono jest - system działa sprawnie, gdy go brak - system pada. A jak wiadomo, zaufanie buduje się

31 M. Grzybowski, Działalność pomocowa Bankowego Funduszu Gwarancyjnego, w: Systemy gwarantowania depozytów w Polsce i na świecie. Dziesięć lat Bankowego Funduszu Gwarancyjnego, red. W. Baka, PWE, Warszawa 2005, s. 105. 
długo, ale szybko można je stracić”32. Zarówno z jednym, jak i z drugim kryterium łączy się problem ryzyka i konieczności systematycznego i konsekwentnego stosowania systemu zarządzania ryzykiem jako elementu zarządzania bankiem. Ilustruje to przedstawiony schemat ${ }^{33}$.

\begin{tabular}{|l|l|}
\hline \multicolumn{2}{|c|}{ System zarządzania bankiem } \\
\hline system zarządzania ryzykiem & system kontroli wewnętrznej \\
- identyfikacja ryzyka & - audyt wewnętrzny \\
- pomiar lub szacowanie (jeśli dokładny pomiar jest & - badanie zagadnień działania z przepisami prawa \\
niemożliwy) ryzyka & i regulacjami wewnetrznymi \\
- monitorowanie ryzyka & - mechanizmy kontroli ryzyka \\
\hline
\end{tabular}

Przychylamy się przy tym do stanowiska, według którego zarządzanie ryzykiem powinno być realizowane zgodnie z następującymi zasadami:

- „zarządzanie ryzykiem powinno być inicjowane na najwyższym szczeblu i kolejno uwzględniać szczeble niższe [...],

- zarządzanie ryzykiem ma charakter kompleksowy, tj. obejmuje wszystkie kategorie ryzyka,

- integralnymi składnikami systemu zarządzania ryzykiem spełniającymi funkcje pomocnicze są: dział kontroli wewnętrznej, działy administracji, księgowości i sprawozdawczości, wewnętrzny dział rewizji, kadr i technologii informatycznej [...], - jasno sprecyzowane cele i strategie zarządzania powinny być wdrażane za pośrednictwem przyjętego systemu procedur i mechanizmów kontroli”34.

Do podstawowych rodzajów ryzyka w działalności operacyjnej banku wpływających na jego stabilność i bezpieczeństwo zaliczyć należy: ryzyko utraty płynności, ryzyko kredytowe, ryzyko stopy procentowej i ryzyko kursowe. Należy tu wyraźnie podkreślić, że ryzyka praktycznie nie da się z działalności banku wyeliminować. Chodzi bardziej o jego identyfikację, ciągłe monitorowanie czynników na niego wpływających, sterowanie, czyli ograniczanie działań na rzecz jego ograniczenia oraz kontrolowanie działań, które pozwalają na opanowanie zjawiska i wykorzystania jego znajomości do maksymalizowania wielkości, na które wcześniej wskazywaliśmy jako na wielkości decydujące o kryterium rynkowym.

Oczywiście specyfika poszczególnych rodzajów ryzyka i jego wpływu na stabilność i bezpieczeństwo banku jest zróżnicowana ${ }^{35}$.

32 C. Wójcik, op.cit.

33 J. Koleśnik, op.cit., s. 71.

34 M.S. Wiatr, Skuteczność zarządzania ryzykiem kredytowym we wspótczesnym otoczeniu kryzysowym. Przykład Polski, w: Instrumenty i regulacje bankowe w czasie kryzysu, red. J. Nowakowski, Difin, Warszawa 2010, s. 55-56.

35 Por. B. Pietrzak, op.cit., s. 80-84. 
W przypadku ryzyka płynności należy uwzględnić następujące fakty związane $\mathrm{z}$ istotą tej płynności:

- nie jest ona wielkością stałą; zmienia się pod wpływem dużej ilości czynników związanych zarówno z przyjętą strategią banku, jak i realizacją wielu operacji;

- określając rozmiary płynności, należy pamiętać o tym, że duża płynność zwiększa bezpieczeństwo działalności banku i wzmacnia jego wiarygodność, ale jednocześnie wpływa na wyższe koszty, bowiem zwiększanie płynności, przy danych zasobach banku, oznacza zmniejszenie środków na tzw. pracujące aktywa, które przynoszą określony dochód.

Do działań zapobiegających utracie płynności należy zaliczyć: monitorowanie bieżącej i przewidywanej sytuacji w strukturze aktywów i pasywów, zachowań klientów, pozycji banku na rynkach finansowych i w kontraktach z instytucjami tych rynków, analiza terminów zapadalności aktywów i wymagalności pasywów, analiza przepływów gotówkowych oraz wyznaczanie limitów płynności, opracowanie wewnętrznych reguł, procedur i limitów ostrożnościowych w tej dziedzinie.

Z kolei czynnością zapobiegającą negatywnym skutkom ryzyka kredytowego jest głównie rzetelna ocena zdolności kredytowej klienta banku. Ponieważ jednak zdarzają się sytuacje, które wynikają z:

- braku dostatecznego rozeznania sytuacji nowych podmiotów gospodarczych ubiegających się po raz pierwszy o kredyt;

- niestabilności warunków gospodarowania utrudniającą przewidywaną kondycję finansową kredytobiorcy, należy stosować możliwe do wykorzystania zabezpieczenie materialne i prawne.

Występujące często ryzyko stopy procentowej powoduje, że bank nie może ograniczać się do biernego śledzenia tego, aby różnica w oprocentowaniu aktywów i pasywów była jak największa. Należy badać przewidywane trendy rynkowej stopy procentowej i dokonywać zmian struktury aktywów oraz pasywów, dbać o zawieranie transakcji z klauzulą zmiany oprocentowania oraz zabezpieczanie się za pomocą nowych instrumentów, zwłaszcza w transakcjach terminowych.

W odniesieniu do ryzyka kursowego, które ma miejsce wówczas, gdy na skutek wahań kursu walutowego dochodzi do zmian wartości poszczególnych elementów aktywów i pasywów banku wyrażonych w walucie obcej, właściwym, przynoszącym pozytywne skutki działaniem jest szczegółowe identyfikowanie i monitorowanie czynników, które mogą decydować o niekorzystnych wahaniach kursu walutowego.

Uwzględniając systemowe i operacyjne podejście do analizowanych tytułowych problemów tego opracowania, chcielibyśmy zwrócić uwagę na fakt, że niezależnie od koniecznych z punktu widzenia stabilności i bezpieczeństwa sektora bankowego działań na rzecz ograniczenia poszczególnych rodzajów ryzyka (płynności, kredytowego, 
stopy procentowej, kursowego) problemem szczególnej wagi jest precyzyjne i skuteczne zarządzanie aktywami oraz pasywami banków. Banki komercyjne jako instytucje zaufania publicznego, gospodarujące środkami powierzonymi im przez klientów muszą być w swojej działalności szczególnie ostrożne. Jej charakter musi odpowiadać wspomnianemu wcześniej dwukryterialnemu działaniu banków. Jeśli przyjąć, iż ze względu na kryterium rynkowe podstawowym celem banku komercyjnego jest dążenie do osiągania optymalnego wyniku finansowego czy też obecnie coraz częściej wartości banku, to z jednej strony zarządzanie aktywami i pasywami musi uwzględniać takie kształtowanie struktury ilościowej i jakościowej składników obu stron bilansu banku, która pozwala na ową optymalizację wyniku finansowego, z drugiej zaś, ponieważ funkcjonowanie banku obarczone jest ryzykiem, które wpływa na możliwości urzeczywistnienia celu, należy bezwzględnie przestrzegać zasady, iż zarządzanie aktywami i pasywami musi polegać na ciągłym monitorowaniu oraz kontrolowaniu różnych rodzajów ryzyka, które prowadzą do ukształtowania wielkości i struktury aktywów oraz pasywów umożliwiających minimalizację ryzyka.

W warunkach względnie ustabilizowanej sytuacji w systemach finansowych, z jaką mieliśmy do czynienia w okresie przedkryzysowym, wydawało się, iż kryteria te zbliżają się do siebie lub że możliwość powstawania sprzeczności między nimi zmniejsza się, co miałoby oznaczać zachowanie właściwych proporcji między kryterium rynkowym i kryterium zaufania publicznego w funkcjonowaniu banków komercyjnych. Niestety, wydarzenia, które doprowadziły do kryzysu, wykazały, że proporcje te zostały pogwałcone. Kryterium zaufania publicznego nie było dostatecznie docenione. Nieraz za wszelką cenę starano się, aby kryterium rynkowe stało się kryterium dominującym.

Czynnikami o znaczącym charakterze, oddziałującym coraz silniej na bezpieczeństwo i stabilność systemu bankowego, ściśle powiązanymi ze wskazanym wcześniej kryterium zaufania społecznego i kryterium rynkowym, opartym na dążeniu do optymalizacji zysku czy wartości banku, na który pragniemy na zakończenie zwrócić uwagę, jest społeczna odpowiedzialność biznesu oraz reputacja banku.

Słusznie pisze L. Dziawgo, iż „zapewnienie prawidłowego działania sektora finansowego należy postrzegać jako połączenie urzędowego nadzoru zewnętrznego, nadzoru wewnętrznego w instytucjach finansowych oraz właśnie społecznej odpowiedzialności biznesu"36.

Doświadczenia ostatniego kryzysu w pełni potwierdzają słuszność powyższego twierdzenia. Brak uwzględnienia w bieżącej działalności banków oraz w strategiach

36 L. Dziawgo, Społeczna odpowiedzialność biznesu a bezpieczeństwo systemu bankowego, w: Stabilność i bezpieczeństwo systemu bankowego, red. J. Nowakowski, T. Famulska, Difin, Warszawa 2008, s. 119. 
długookresowych odpowiedzialności za czynniki sprzyjające rozwojowi banków, ale jednocześnie uwzględniających preferencje interesariuszy doprowadził do katastrofalnych skutków nie tylko w opisywanym sektorze, ale w całym systemie finansowym oraz w sferze realnej gospodarek.

Dobrze oczywiście byłoby (i taki pożądany stan byłby najbardziej skutecznie działającym czynnikiem), gdyby tą społeczną odpowiedzialnością wzajemnie podzieliły się banki z interesariuszami. Ich działania na rzecz urzeczywistniania wskazanej idei powinny być poddane, jak to określa w swoim artykule L. Dziawgo, wykreowanemu nadzorowi społecznemu, a jego zadaniem „byłoby uświadamianie zagrożeń, pomocy w ich identyfikacji i wyzwalanie inicjatywy przeciwdziałania zagrożeniom" ${ }^{37}$. To oczywiście wspomagałoby skuteczność tej idei, ale sposoby i instrumenty operacyjnego jej urzeczywistnienia powinny być wkomponowane w bieżące i perspektywiczne działanie instytucji finansowych, w tym w szczególności banków ${ }^{38}$.

Drugi ze wskazanych czynników: kształtowanie reputacji banku traktowane jest jako metoda (sposób) jego funkcjonowania cechująca się spójnym i stabilnym wzorem postępowania czyniącym bank w pełni wiarygodnym. Służy więc też stabilności i bezpieczeństwu banku.

Natomiast T. Dąbrowski, opierając się na wynikach badań M.E. Siltaoji zaprezentowanych w pracy Value Priorities as Combinning Core Factorsbetween CSR and Reputation - a Qualitative Study ${ }^{39}$, pisze, iż „CRS wywiera szczególnie duży wpływ na reputację, gdy działania z tego zakresu stanowią odzwierciedlenie wartości etycznych obecnych w kulturze organizacyjnej podmiotu i są elementem sposobu prowadzenia biznesu"40. Tak więc ciągła dbałość o wysoką kulturę organizacyjną i skuteczne oddziaływanie banku na czynniki ją określające stanowi ważny element jego stabilności i bezpieczeństwa.

\section{Zakończenie}

Sądzimy, że przedstawione rozważania i efekty naszych zabiegów dotyczące wskazania na wybrane - systemowe i operacyjne - uwarunkowania stabilności

\footnotetext{
37 Ibidem, op.cit., s. 124.

38 Szerzej zob. Mechanizmy stabilności systemu finansowego, red. A. Alińska, K. Wasiak, C.H. Beck, Warszawa 2016.

39 „Journal of Business Ethics” 2006, Vol. 68, No. 1.

40 T. Dąbrowski, Kształtowanie reputacji banku komercyjnego. Podejście symboliczne i substancjalne, Oficyna Wydawnicza SGH, Warszawa 2016, s. 137.
} 
i bezpieczeństwa sektora bankowego jako wiodącego ogniwa systemu finansowego, uwzględniające przy tym współczesne wymogi, potwierdzają zasadność twierdzenia, że to w nich tkwią istotne rezerwy poprawy sytuacji bieżącego i perspektywicznego funkcjonowania instytucji finansowych, w tym w szczególności banków. Dotyczy to zwłaszcza wybranych i poddanych w artykule analizie cech dwu członów systemu bankowego, tj. banku centralnego i banków komercyjnych, związanych z siecią bezpieczeństwa bankowego i zarządzaniem bankami. Interpretacja i wykorzystywanie instrumentów tkwiących w sieci bezpieczeństwa oraz w elementach zarządzania bankami tworzą zespół uwarunkowań działania tych dwu ogniw umożliwiających realizację zadań decydujących o stabilności i bezpieczeństwie systemu bankowego.

Konstrukcja sieci bezpieczeństwa finansowego powinna uwzględniać wyraźne określenie kompetencji każdego jej ogniwa oraz tworzenia formalnych i realnych warunków zapewniających pełną koordynację między nimi.

Podsumowując, warto zatem zwrócić uwagę na konieczność koordynacji działań władz fiskalnych i monetarnych, jednak jako członów niezależnych i wiarygodnych. Efektywna koordynacja dwu głównych ogniw polityki finansowej państwa, tj. polityki fiskalnej i monetarnej, może przyczynić się do wzmocnienia efektów działania każdej z nich. Konieczna jest przy tym konsekwentna realizacja przez bank centralny przypisanych mu funkcji, a także wynikających z nich praktycznych zadań. Naszym zdaniem istotne jest umieszczenie $\mathrm{w}$ priorytetowych zadaniach banku centralnego dbałości o stabilność systemu finansowego, w tym zwłaszcza bankowego, oraz zapewnienie odpowiednich relacji między stabilnością monetarną a stabilnością finansową. Wydaje się, że istotne jest uwzględnienie we wszystkich obszarach działalności banku centralnego jakościowych aspektów jego funkcjonowania, tj. autonomii, wiarygodności, przejrzystości oraz demokratycznej odpowiedzialności.

Jeśli chodzi o funkcjonowanie drugiego członu systemu bankowego, to za ważne oraz potrzebne uważamy, po pierwsze, przywrócenie właściwych proporcji pomiędzy kryterium rynkowym i kryterium zaufania publicznego (określających interesy banku i jego klientów) w bieżącej działalności banków komercyjnych i perspektywicznych strategiach ich rozwoju. Dużą rolę odgrywa tu system zarządzania aktywami i pasywami banku. Ponadto, wykorzystanie ścisłych związków między czynnikami decydującymi o bezpieczeństwie systemu bankowego a czynnikami określającymi stabilność sektora bankowego do nadania najwyższej rangi kwestiom zaufania oraz ograniczania ryzyka w działalności banków. Kolejna ważna kwestia to uwzględnienie idei społecznej odpowiedzialności biznesu w strategiach i operacyjnych działaniach banków komercyjnych oraz aktywnego kształtowania ich reputacji. Na wzmocnienie stabilności i bezpieczeństwa systemu finansowego wpływają także: po pierwsze, bezwzględne przestrzeganie przez rząd (Ministerstwo Finansów) dbałości o dyscyplinę 
budżetową, racjonalność wydatków publicznych oraz skuteczność ustanowionych norm związanych z gospodarowaniem środków publicznych i ostrożnością w funkcjonowaniu instytucji finansowych. Po drugie zaś - aktywne działanie na rzecz tworzenia ponadnarodowych regulacji i instytucji przeciwdziałających narastaniu negatywnych skutków destabilizacji systemów bankowych.

Systematyczna i konsekwentna realizacja programów wzmacniania stabilności i bezpieczeństwa systemu bankowego jest bezwzględną koniecznością. Dotyczy to również (a nawet w szczególności) wymienionych wyżej wymogów.

\section{Bibliografia}

Allen W., Wood G., Defining and achieving financial stability, „Journal of Financial Stability" June 2006, s. 152-172.

Bagehot W., Lombard Street: A Description of the Money Market, H.S. King, London 1873.

Banki centralne wobec kryzysu ekonomicznego, red. J. Osiński, Oficyna Wydawnicza SGH, Warszawa 2010.

Banki w społecznej gospodarce rynkowej w świetle doświadczeń $z$ kryzysu i stanu rozwoju rynku finansowego, red. S. Flejterski, A. Gospodarowicz, Związek Banków Polskich, Warszawa 2014.

Capiga M., Gradoń W., Szustak E., Sieć bezpieczeństwa finansowego, CeDeWu Pl., Warszawa 2010.

Chant J., Financial Stability as a Policy Goal, w: Essays on Financial Stability, „Technical Report Bank of Canada" September 2003, No. 95.

Crockett A., Why is Financial Stability a Goal of Public Policy?, w: Maintaining Financial Stability in a Global Economy, Symposium Proceedings, Federal Reserve Bank of Kansas City, August 1997, s. 55-96.

Daniluk D., Niemirka S., Nadzór bankowy w Polsce, „Bank i Kredyt” 2005, nr 9.

Davis E., A Typology of Financial Instability, „Oesterreichische Nationalbank (Central Bank of Austria) Financial Stability Report" 2001, No. 2, s. 92-110.

Dąbrowski T., Kształtowanie reputacji banku komercyjnego. Podejście symboliczne i substancjalne, Oficyna Wydawnicza SGH, Warszawa 2016.

Dobrzańska A., Polityka makroostrożnościowa - zagadnienia instytucjonalne. Teoria i dotychczasowe doświadczenia w Unii Europejskiej, „Materiały i Studia NBP” 2014, nr 307.

Dziawgo L., Społeczna odpowiedzialność biznesu a bezpieczeństwo systemu bankowego, w: Stabilność i bezpieczeństwo systemu bankowego, Difin, Warszawa 2008.

Europejska Unia Bankowa, red. M. Zaleska, Difin, Warszawa 2015. 
Ferguson R., Should Financial Stability Be an Explicit Central Bank Objective?, w: Monetary Stability, Financial Stability and the Business Cycle: Five Views, „BIS Paper” September 2003, No. 18, s. 7-15.

Flejterski S., Zaufanie do instytucji bankowo-finansowych jako fundament stabilnego systemu finansowego, w: Stabilność i bezpieczeństwo systemu bankowego, red. J. Nowakowski, T. Famulska, Difin, Warszawa 2008.

Foot M., What is "financial stability" and how do we get it?, The Roy Bridge Memorial Lecture, Financial Services Authority, April 2003.

Grzybowski M., Działalność pomocowa Bankowego Funduszu Gwarancyjnego, w: Systemy gwarantowania depozytów w Polsce i na świecie. Dziesięć lat bankowego Funduszu Gwarancyjnego, red. W. Baka, PWE, Warszawa 2005.

Grzywacz J., Podstawy bankowości, Difin, Warszawa 2008.

Humphrey T.M., Lender of last resort: What it is, whence it came, and why the Fed isn't it, „Cato Journal” 2010, Vol. 30, No. 2.

Koleśnik J., Bezpieczeństwo systemu bankowego. Teoria i praktyka, Difin, Warszawa 2011.

Kornik D., Odpowiedzialność banku komercyjnego. Próby syntezy, Difin, Warszawa 2009.

Kowalak M., Jakościowe aspekty polityki współczesnego banku centralnego, „Bank i Kredyt" 2006, nr 3.

Lager J., Monitoring Financial System Stability, „Reserve Bank of Australia Bulletin” October 1999.

Laurens B., Piedra E.G., de la, Coordination of Monetary and Fiscal Policies, „IMF Working Paper" March 1998, No. 98/25.

Matysek-Jędrych A., Odpowiedzialność i przejrzystość banku centralnego w działaniach na rzecz stabilności finansowej, „Materiały i Studia NBP” 2014, nr 303.

Mishkin F., The Causes and Propagation of Financial Instability: Lessons for Policymakers, w: Maintaining Financial Stability in a Global Economy, Symposium Proceedings, Federal Reserve Bank of Kansas City, August 1997, s. 55-96.

Mishkin F., Financial Stability and the Macroeconomy, „Central Bank of Iceland Working Paper" May 2000, No. 9.

Mishkin F., Global Financial Instability: Framework, Events, Issues, „Journal of Economic Perspectives" Autumn 1999, Vol. 13, No. 4, s. 3-20.

Padoa Schioppa T., Central Banks and Financial Stability: Exploring a Land in Between, paper presented at the Second ECB Central Banking Conference, Frankfurt am Main, 24-25 October 2002.

Pietrzak B., Bank centralny jako instytucja bezpieczeństwa finansowego, w: Ekonomia, Społeczeństwo, Polityka, red. A. Zawistowski, Oficyna Wydawnicza SGH, Warszawa 2012.

B. Pietrzak, System bankowy, w: System finansowy w Polsce, t. 1, red. B. Pietrzak, Z. Polański, B. Woźniak, Wydawnictwo Naukowe PWN, Warszawa 2008. 
Pietrzak B., Wasiak K., O potrzebie koordynacji polityki fiskalnej i monetarnej, w: O nowy model działalności regulacyjnej państwa w sferze finansów. Ksiązka jubileuszowa prof. zw. dr. hab. S. Owsiaka, red. A. Moździerz, PWE, Warszawa 2011.

Polityka monetarna i fiskalna a stabilność sektora finansowego, red. A. Alińska, CeDeWu, Warszawa 2012.

Polska wobec kryzysu gospodarczego, NBP, Warszawa 2009.

Pyka J., Bank centralny na współczesnym rynku pieniężnym, C.H. Beck, Warszawa 2010.

Raport o stabilności systemu finansowego, Departament Systemu Finansowego NBP, Warszawa 2014.

Rozwój systemu finansowego w Polsce w 2012 r., NBP, Warszawa 2014.

Schinasi G., Defining Financial Stability, „IMF Working Paper” October 2004, No. WP/04/187.

Sławiński A., Stabilność finansowa, w: Polityka pieniężna, red. A. Sławiński, C.H. Beck, Warszawa 2011.

Smaga P., Rola banku centralnego w zapewnieniu stabilności finansowej, CeDeWu, Warszawa 2014.

Stabilność finansowa, red. M. Iwanicz-Drozdowska, NBP, Warszawa 2014.

Stabilność i bezpieczeństwo systemu bankowego, red. J. Nowakowski, T. Famulska, Difin, Warszawa 2008.

Stabilność systemu finansowego - instytucje, instrumenty, uwarunkowania, red. A. Alińska, B. Pietrzak, CeDeWu, Warszawa 2012.

System finansowy w Polsce, t. 1, red. B. Pietrzak, Z. Polański, B. Woźniak, Wydawnictwo Naukowe PWN, Warszawa 2008.

Thornton H., The evidence given by Henry Thornton before the Committees of Secrecy of the Two Houses of Parliament on the Bank of England, March and April 1797.

Wasiak K., Stabilność systemu finansowego a cykl koniunkturalny, w: Polityka monetarna i fiskalna a stabilność sektora finansowego, red. A. Alińska, CeDeWu, Warszawa 2012, s. $148-149$.

Wiatr M.S., Skuteczność zarządzania ryzykiem kredytowym we współczesnym otoczeniu kryzysowym. Przykład Polski, w: Instrumenty i regulacje bankowe w czasie kryzysu, red. J. Nowakowski, Difin, Warszawa 2010.

Wojtyna A., Wyzwania dla banków centralnych, „Rzeczpospolita” 15 października 2010.

Wójcik C., Co z drugą falą kryzysu, „Rzeczpospolita” 25 sierpnia 2011.

Zaleska M., Społeczeństwa szybko zapominają o przyczynach kryzysów, „Obserwator Finansowy NBP” wrzesień 2015, www.obserwatorfinansowy.pl 


\section{Stability and security of the banking system - institutional and operational aspects}

This article attempts to systematize the institutional and operational conditions of stability and security of the banking system. The intention of the authors is to analyse some factors strongly affecting the functions and principles of two members of modern banking systems - the central bank and commercial banks. The authors start the analyses by defining stability and security of the banking system. Then point out to the role of the various segments of the financial safety net in providing conditions for stable and secure system, and determine the necessary requirements of the stabilization as demanded from the banking institutions management system. In conclusion, they define the set of requirements (institutional and operational) necessary for achieving the stability and security of the banking system.

Keywords: banking system, banking system stability, central bank

\section{Stabilité et sécurité du système bancaire - aspects institutionnels et opérationnels}

Larticle vise à systématiser les conditions institutionnelles et opérationnelles de la stabilité et de la sécurité du système bancaire. L'intention des auteurs est d'analyser certains facteurs affectant de manière importante les fonctions, principes, méthodes et façon du fonctionnement des deux éléments du système bancaire moderne - la banque centrale et les banques commerciales. En premier lieu, les auteurs définissent la stabilité et la sécurité du système bancaire. En second lieu, ils soulignent le rôle des différents segments du filet de sécurité financier pour assurer les conditions d'un système stable et sûr. Ensuite, ils définissent les exigences nécessaires d'une telle stabilité qui doivent être remplies par le système de la gestion des institutions bancaires. En conclusion, en résumant les résultats de l'analyse effectuée, ils définissent un ensemble des conditions (institutionnelles et opérationnelles) facilitant la réalisation des tâches qui garantissent la stabilité et la sécurité du système bancaire.

Mots-clés: système bancaire, stabilité du système bancaire, banque centrale 


\section{Стабильность и безопасность банковской системы - институциональные и операционные аспекты}

В статье предпринята попытка систематизировать институциональные и операционные условия стабильности и безопасности банковской системы. Авторы намериваются провести анализ выбранных факторов, оказывающих сильное влияние на функции, принципы, способы и методы работы двух элементов современных банковских систем, т. е. центрального банка и коммерческих банков. Сначала авторы уточняют понятие стабильности и безопасности банковской системы. Затем указывают на роль различных сегментов сети финансовой безопасности в обеспечении условий для стабильности и безопасности системы. Определяются необходимые требования стабилизации в отношении системы управления банковскими учреждениями. В заключение, подводя итоги анализа, указывается на набор требований (организационных и операционных) для достижения стабильности и безопасности банковской системы.

Ключевые слова: банковская система, стабильность банковской системы, центральный банк 